\title{
Morphological and Chemical Properties of Particulate Matter in the Dammam Metropolitan Region: Dhahran, Khobar, and Dammam, Saudi Arabia
}

\author{
Bassam S. Tawabini, ${ }^{1}$ Taoreed T. Lawal, ${ }^{1,2}$ Abdulaziz Shaibani, ${ }^{1}$ and Ashraf M. Farahat ${ }^{3,4}$ \\ ${ }^{1}$ Geosciences Department, King Fahd University of Petroleum and Minerals (KFUPM), Dhahran 31261, Saudi Arabia \\ ${ }^{2}$ Department of Industrial Hygiene, College of Engineering, West Virginia University, Morgantown, WV 26505, USA \\ ${ }^{3}$ Physics Department, King Fahd University of Petroleum and Minerals (KFUPM), Dhahran 31261, Saudi Arabia \\ ${ }^{4}$ Department of Physics, Faculty of Science, Alexandria University, Alexandria, Egypt
}

Correspondence should be addressed to Ashraf M. Farahat; farahata@kfupm.edu.sa

Received 9 July 2017; Revised 6 November 2017; Accepted 16 November 2017; Published 20 December 2017

Academic Editor: Junshik Um

Copyright (C) 2017 Bassam S. Tawabini et al. This is an open access article distributed under the Creative Commons Attribution License, which permits unrestricted use, distribution, and reproduction in any medium, provided the original work is properly cited.

\begin{abstract}
Characteristics of airborne particulate matter (PM) as well as its levels in air samples collected from selected sites within cities of Dhahran, Khobar, and Dammam, in the Eastern Province of Saudi Arabia, are investigated. Concentration levels of the 10 microns' PM (i.e., $\mathrm{PM}_{10}$ ) are determined using the gravimetric technique. Morphological and chemical characteristics of the PM collected from the sampling cities are studied using Field-Emission Scanning Electron Microscopy (FESEM), energy dispersive X-ray (EDX), and X-Ray Fluorescence (XRF). Moreover, levels and types of hazardous materials related to these samples are assessed using Inductively Coupled Plasma-Optical Emission Spectroscopy (ICP-OES). Results revealed that the average concentration levels of $\mathrm{PM}_{10}$ were approximately 177, 380, and $126 \mu \mathrm{g} / \mathrm{m}^{3}$ in Dhahran, Khobar, and Dammam, respectively. The structure of PM collected in Dhahran was mainly platy and rod-like shaped with a size between 2 and $6 \mu \mathrm{m}$, while PM collected in Khobar was mostly irregular in form, with a size range between 2 and $8 \mu \mathrm{m}$, and Dammam's PM was rounded and between 1 and $3 \mu \mathrm{m}$ in size. Both EDX and $\mathrm{XRF}$ results indicate relatively high weight $\%$ of $\mathrm{C}, \mathrm{O}, \mathrm{Si}, \mathrm{F}$, and $\mathrm{Ca}$ with lower weight $\%$ of $\mathrm{Na}, \mathrm{Mg}$, and $\mathrm{K}$ at the 3 cities. Finally, the study shows that $\mathrm{Ba}$ and $\mathrm{Zn}$ were the main trace metals associated with the collected PM in the 3 cities.
\end{abstract}

\section{Introduction}

Particulate matter (PM) is a very vital pollutant that alters the ecosystem, human health, and environment as well as air quality. Equivalent Aerodynamic Diameters (EAD) method is the basic technique used to classify PM [1], where particles could be classified into $\mathrm{PM}_{10}, \mathrm{PM}_{2.5}$, and $\mathrm{PM}_{1.0}$ representing their $10,2.5$, and $1 \mu \mathrm{m}$ sizes, respectively $[2,3] . \mathrm{PM}_{10}$ particles are referred to as "inhalables" and usually trapped in mucus linings and may cause significant health effects to the respiratory system. Human health, ecosystem, and climate are affected by PM $[4,5]$, with high correlation found between daily mortality and PM concentration in urban areas [5]. PM has been universally regarded to be of extreme importance with worldwide organizations established to implement and monitor air quality standards and levels.
Several efforts have been conducted to determine the characteristics of particulate matter samples collected in both indoor and outdoor environments around the globe. Wu et al. [6] studied the attributes of $\mathrm{PM}_{10}$ and $\mathrm{PM}_{2.5}$ at Mount Wutai Buddhism Scenic Spot, Shanxi China. Ny and Lee [7] studied the size distribution of PM and some elements it contains within an industrial city in Korea. In another research, Ahmady-Birgani et al. [8] investigated the mineralogy and geochemistry of PM in Western Iran.

Field-Emission Scanning Electron Microscopy (FESEM) coupled with energy dispersive microanalysis has been used globally to study the chemical and morphological characteristics of airborne particles [9-11]. FESEM-EDX has been exploited in many reviews $[12,13]$ to ascertain the difference in morphology and structure, as well as estimating the elemental component of the particulate aerosols. Also, it was 
used to identify PM's likely emission sources and their link to the transport of pollutants from differently polluted areas [14].

Kingdom of Saudi Arabia is well known for its major dust storms which have great impacts on the distribution of the particulate matter in the Kingdom [15]. Numerous studies investigated PM categorization over the Arabian Peninsula and the Mideastern region using airborne and Aerosol Robotic Network (AERONET) ground observations $[2,3,16]$; however ground observations are very limited due to the existence of only two AERONET stations in Saudi Arabia, namely, the Solar Village $\left(24^{\circ} \mathrm{N}, 46^{\circ} \mathrm{E}\right)$ and KACST $\left(22^{\circ} \mathrm{N}, 39^{\circ} \mathrm{E}\right)$. Hussein et al. [17] carried out a study, in Jeddah's urban atmosphere, on the concentration of particles heavier than one-quarter of a micron and particulate matter, during the year 2012. An investigation by Alharbi et al. [16] showed that the chemical characteristics of PM concentration in Saudi Arabia capital, Riyadh, during weekdays were 17\% higher compared to weekends during the period between September 2011 and September 2012.

Eastern Province (EP) of Saudi Arabia is prominent for PM due to mega construction activities [18]; however, despite the fame, there is little information on the mineralogical composition and characteristics of the PM samples. Hence, this research was embarked on to study the pattern of particulate matter less than $10 \mu \mathrm{m}\left(\mathrm{PM}_{10}\right)$ produced within 3 major cities (Dhahran, Dammam, and Khobar) of EP, Saudi Arabia, to determine their elemental composition, which may enter human's respiratory system through inhalation and compare the elemental concentration with available worldwide standards. The research also investigates the size, shape, and elemental composition of the pollutants as well as the mineral composition of the particles. These observations would provide public and private organizations, government regulatory bodies, and scientific communities with vital information that would be useful in protection of public health and welfare.

\section{Methodology}

2.1. Description of the Sampling Sites. Dammam metropolitan area is the largest metropolitan area in the EP of Saudi Arabia; it is formed by three main neighboring cities: Dhahran, Khobar, and Dammam. It has an estimated population of $\sim 3$ million (https://www.stats.gov.sa/). These three cities are known for their major chemical, petrochemical, and oil industries. The area also includes a variety of natural landscapes, parks, and beaches with a recreational coastline to the Arabian Gulf.

Three (3) locations were selected in each city to collect air samples using $\mathrm{PM}_{10}$ filter. The samples were collected over a period of 24 hours for 7 days at each location, as shown in Figure 1, from Oct. 10 to Dec. 12, 2015. Detailed latitudelongitude, elevation, and residential and traffic conditions for each site are displayed in Table 1. Samples were collected at Dhahran during Oct. 01-Oct. 21 [day of the year (DOY) 274-294] as location 1 (Oct. 01 to Oct. 07); location 2 (Oct. 08 to Oct. 14); location 3 (Oct. 15 to Oct. 21). At Khobar during Oct. 22-Dec. 11 [DOY: 296-316] as location 1 (Oct. 22-Oct.

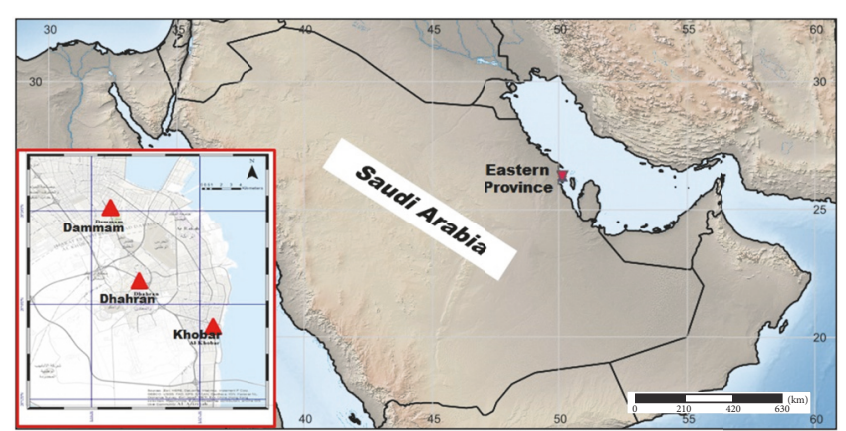

Figure 1: Map of sampling site.

29); location 2 (Oct. 30-Nov. 5); location 3 (Nov. 06-Dec. 11). At Dammam during Nov. 14-Dec. 23 [DOY: 318-357] as location 1 (Nov. 14-Nov. 20), location 2 (Nov. 21-Dec. 16), and location 3 (Dec. 17-Dec. 23).

2.2. Sample Collection. Air samples were collected using HiVol 3000 air sampling device (Ecotech, Australia) with $\mathrm{PM}_{10}$ size selective inlet. The sampler was set to a steady sampling speed of 50 liters/mins, with a volumetric flow rate ranging between 45 and $96 \mathrm{~m}^{3} / \mathrm{hr}$ and having a flow precision and correctness exceeding $\pm 1 \mathrm{~m}^{3} / \mathrm{hr}$. The flow repeatability was $1.0 \%$ of the reading and the capability of the vacuum is 140 bars. The particles $\left(\mathrm{PM}_{10}\right)$ were collected on $8 \times 10$ inch Pallflex EMFAB-TX40H120-WW filter membrane made with glass microfibers of borosilicate origin that have been protected with laced glass cloth.

2.3. Sample Preparation for Trace Metal Analysis. Onequarter of the collected filter was cut into small pieces and weighted using Mettler Toledo JL602GE analytical digital balance after which the filter pieces were put into a $100 \mathrm{~mL}$ beaker and sprayed with distilled and deionized water. Aqua regia solution was prepared using distilled nitric acid $\left(\mathrm{HNO}_{3}\right)$ and concentrated hydrochloric acid ( $\mathrm{HCl}$ ) (ratio 1 to 3 ). More distilled water was added to the mixture until the mark and was then stirred inside the fume hood. The solution, including the pieces of filter sample, was then heated in an oven for 3-4 hours at a temperature of around $130^{\circ} \mathrm{C}$ until it reaches near dryness after which the solution was cooled down to room temperature. The mixture was then filtered with size 42 Whatman filter paper. The volume of the filtrate was then topped up to $50 \mathrm{~mL}$ using water.

The acid digest (filtrate) was finally analyzed as per the work of Sadiq and Mian [19]. A total of 9 samples were analyzed for each sampling site along with 2 blank filter samples for QA/QC work.

\subsection{PM Characterization}

2.4.1. Gravimetric Analysis. Masses of the airborne PM collected in different locations were gravimetrically determined by calculating the difference in weights of the filter before and after sample collection. The filters were weighed using the Mettler JL602GE scale which has a maximum weighing 
TABLE 1: Information on the sampling areas in Dhahran, Khobar, and Dammam.

\begin{tabular}{|c|c|c|c|}
\hline Sampling point & Area & $\begin{array}{l}\text { Geographical } \\
\text { position }\end{array}$ & Altitude \\
\hline $\begin{array}{l}\text { Location 1: } \\
\text { City of Dhahran }\end{array}$ & $\begin{array}{c}\text { King Fahd University campus } \\
\text { (main university road) } \\
\text { Light traffic }\end{array}$ & $\begin{array}{c}50^{\circ} 8^{\prime} 24.5904^{\prime \prime} \mathrm{E} \\
26^{\circ} 18^{\prime} 36.54^{\prime \prime} \mathrm{N}\end{array}$ & $85.66 \mathrm{~m}$ \\
\hline $\begin{array}{l}\text { Location } 2: \\
\text { City of Dhahran }\end{array}$ & $\begin{array}{c}\text { King Fahd University campus } \\
\text { Academic area } \\
\end{array}$ & $\begin{array}{c}50^{\circ} 8^{\prime} 35.7144^{\prime \prime} \mathrm{E} \\
26^{\circ} 18^{\prime} 31.6584^{\prime \prime} \mathrm{N} \\
\end{array}$ & $79.23 \mathrm{~m}$ \\
\hline $\begin{array}{l}\text { Location 3: } \\
\text { City of Dhahran }\end{array}$ & $\begin{array}{c}\text { King Fahd University campus } \\
\text { (students' housing) } \\
\text { Residential area }\end{array}$ & $\begin{array}{c}50^{\circ} 8^{\prime} 35.9448^{\prime \prime} \mathrm{E} \\
26^{\circ} 18^{\prime} 39.5856^{\prime \prime} \mathrm{N}\end{array}$ & $64.4 \mathrm{~m}$ \\
\hline $\begin{array}{l}\text { Location } 1: \\
\text { City of Khobar }\end{array}$ & $\begin{array}{l}\text { Thuqba Cemetery (high } \\
\text { populated residential area) }\end{array}$ & $\begin{array}{l}50^{\circ} 11^{\prime} 36.41^{\prime \prime} \mathrm{E} \\
26^{\circ} 15^{\prime} 35.59^{\prime \prime} \mathrm{N}\end{array}$ & $15.02 \mathrm{~m}$ \\
\hline $\begin{array}{l}\text { Location 2: } \\
\text { City of Khobar }\end{array}$ & $\begin{array}{l}\text { Khobar traffic police } \\
\text { (high traffic) }\end{array}$ & $\begin{array}{c}50^{\circ} 11^{\prime} 42.12^{\prime \prime} \mathrm{E} \\
26^{\circ} 16^{\prime} 48.06^{\prime \prime} \mathrm{N}\end{array}$ & $19.01 \mathrm{~m}$ \\
\hline $\begin{array}{l}\text { Location 3: } \\
\text { City of Khobar }\end{array}$ & $\begin{array}{l}\text { Near Al-Farouq Mosque (high } \\
\text { residential and shopping area) }\end{array}$ & $\begin{array}{l}50^{\circ} 11^{\prime} 37.85^{\prime \prime} \mathrm{E} \\
26^{\circ} 16^{\prime} 3.07^{\prime \prime} \mathrm{N}\end{array}$ & $18.0 \mathrm{~m}$ \\
\hline $\begin{array}{l}\text { Location } 1 \text { : } \\
\text { City of Dammam }\end{array}$ & High populated (residential area) & $\begin{array}{l}50^{\circ} 5^{\prime} 41.44^{\prime \prime} \mathrm{E} \\
26^{\circ} 26^{\prime} 2.70^{\prime \prime} \mathrm{N}\end{array}$ & $9.6 \mathrm{~m}$ \\
\hline $\begin{array}{l}\text { Location 2: } \\
\text { City of Dammam }\end{array}$ & High populated (residential area) & $\begin{array}{c}50^{\circ} 5^{\prime} 16.74^{\prime \prime} \mathrm{E} \\
26^{\circ} 25^{\prime} 51.04^{\prime \prime} \mathrm{N} \\
\end{array}$ & $10.0 \mathrm{~m}$ \\
\hline $\begin{array}{l}\text { Location 3: } \\
\text { City of Dammam }\end{array}$ & $\begin{array}{l}\text { Near Imam Hussein Mosque } \\
\text { (high traffic) }\end{array}$ & $\begin{array}{c}50^{\circ} 4^{\prime} 21.68^{\prime \prime} \mathrm{E} \\
26^{\circ} 26^{\prime} 46.60^{\prime \prime} \mathrm{N}\end{array}$ & $5.0 \mathrm{~m}$ \\
\hline
\end{tabular}

capacity of $620 \pm 0.01 \mathrm{~g}$. In order to remove humidity effect and to obtain accurate PM measurements, filters were stored in silica gel desiccators for $24 \mathrm{~h}$ prior to weighing. Field blank filters were also collected to reduce gravimetric bias due to filter handling. Filters were handled with Teflon tape-coated tweezers to reduce the possibility of cross contamination. It is assumed that the particulate deposited on filter papers were uniformly distributed over the entire area of the filter. The average of three (3) weight readings were recorded for each filter (sample). The volume of air pumped by the sampling machine during the sampling period was also recorded and the mass of the PM was calculated in $\mu \mathrm{g} / \mathrm{m}^{3}$.

2.4.2. Morphology and Mineralogy Characterization. The morphology (size and shape) of PM was identified using the TESCAN Lyra3 FESEM unit (Czech Republic). One-fourth of each of the filter samples was taken for the analysis, from which $1 \mathrm{~mm}^{2}$ used for gold coating was at the center and set on tiny stubs for the coating. Ion sputtering was used to place a very thin gold membrane on the samples already placed on the stubs and images were taken for each sample subsequently. The energy dispersive X-ray (EDX), coupled with the FESEM, was also used for spot elemental analysis of the samples.

X-Ray Fluorescence (XRF) spectrometer was used to obtain the elemental constituents of the sample. The XRF model used was JSX-3400RII from JEOL Co., Japan. JSX$3400 \mathrm{RII}$ with X-ray generator of 5 to $50 \mathrm{kV} 1 \mathrm{~mA} 50 \mathrm{~W}$ is the general purpose XRF instrument. It utilizes Silicon (Lithium) detector which has a huge sensitivity to heavy metals and can measure the trace metals within a small time.
2.4.3. Trace Metals Analysis. A dual-view PerkinElmer Optima 8000 Inductively Coupled Plasma-Optical Emission Spectroscopy (ICP-OES) with full-wavelength-range custom designed CCD array detector was used in this study to determine the concentration levels of the trace metals associated with the PM. After PM sampling, the filter paper was cut into 4 equal quarters. One-quarter was weighed, then further cut into small pieces, placed into a $100 \mathrm{~mL}$ glass beaker, and wet with water. A $3: 1\left(\mathrm{HNO}_{3} / \mathrm{HCl}\right)$ aqua regia solution was used to digest the filter paper sample. The beaker that contains the filter paper and the aqua regia solution was placed on a heater for 3-4 hours at about $130^{\circ} \mathrm{C}$ until it reaches near dryness. The beaker was then cooled down to room temperature and their contents were filtered with Whatman filter paper (size 42), and the volume of the filtrate was made up to $50 \mathrm{~mL}$ with distilled water. The digested (filtrate) was used for heavy metal determination using ICP-OES. The digestion procedure is similar to that proposed by Sadiq and Mian [19]. Similarly, for each of the 9 samples analyzed 2 blank samples were also prepared and analyzed in a similar way.

\section{Results and Discussions}

3.1. Levels of PM and Their Distribution. Results show that the $\mathrm{PM}_{10}$ concentration in the three cities is within the range of $\sim 127-380 \mu \mathrm{g} / \mathrm{m}^{3}$. The average $\mathrm{PM}_{10}$ measured at various sampling sites within Dhahran, Khobar, and Dammam is shown in Figure 2. In Dhahran, an overall mean daily $\mathrm{PM}_{10}$ concentration was approximately $177 \mu \mathrm{g} / \mathrm{m}^{3}$ and this is above 50 and $150 \mu \mathrm{g} / \mathrm{m}^{3}$, World Health Organization [20] and United States Environmental Protection Agency [21] 
TABLE 2: Weather conditions on selected days during Oct. and Nov. 2015 (King Abdulaziz Air Base Station) (source: https://www.wunderground $. \operatorname{com} /)$.

\begin{tabular}{|c|c|c|c|c|c|c|}
\hline $\begin{array}{l}\text { Date } \\
2015 \\
\end{array}$ & DOY & $\begin{array}{c}\text { Wind speed } \\
(\mathrm{km} / \mathrm{h})\end{array}$ & $\begin{array}{c}\text { Wind } \\
\text { direction }\end{array}$ & $\begin{array}{l}\text { Visibility } \\
(\mathrm{km})\end{array}$ & Conditions & $\begin{array}{l}\text { Mean temp } \\
{ }^{\circ} \mathrm{C}\end{array}$ \\
\hline Oct. 1 & 274 & 13 & $\mathrm{~W}$ & 10.0 & Clear & 34 \\
\hline Oct. 2 & 275 & 8 & $\mathrm{~W}$ & 8.8 & Clear & 27 \\
\hline Oct. 5 & 278 & 13 & NW & 8.0 & Widespread dust & 34 \\
\hline Oct. 9 & 282 & 10 & SW & 10.0 & Clear & 34 \\
\hline Oct. 20 & 293 & 7 & & 7.4 & Widespread dust & 30 \\
\hline Oct. 22 & 295 & 7 & NW & 6.0 & $\begin{array}{l}\text { Haze-widespread dust } \\
\text { Mist-cloudy }\end{array}$ & 29 \\
\hline Nov. 4 & 308 & 12 & NW & 10.0 & Clear & 24 \\
\hline Nov. 12 & 316 & 17 & $\mathrm{~N}$ & 10.0 & Scattered clouds-partly clouds & 24 \\
\hline Nov. 18 & 322 & 10 & SW & 10.0 & Cloudy & 24 \\
\hline
\end{tabular}

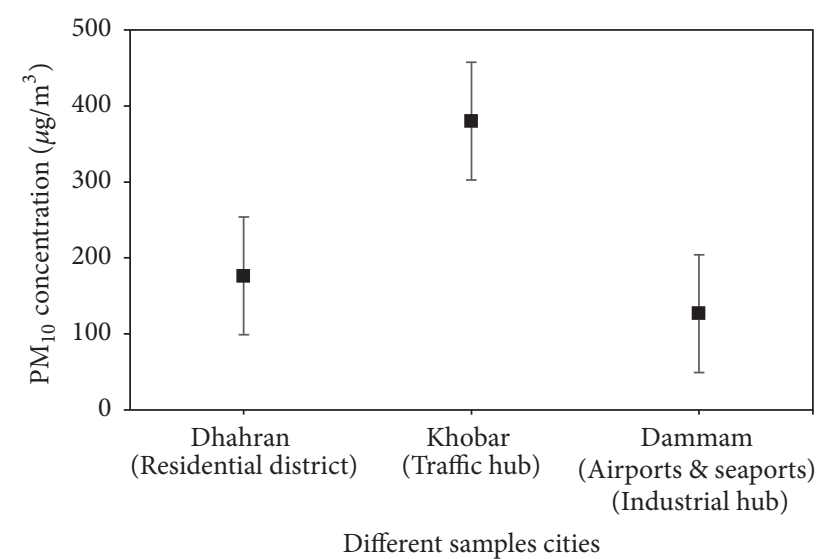

FIGURE 2: Distribution and levels of PM in Dhahran, Khobar, and Dammam.

standards, respectively, but less than PME standards $(350 \mu \mathrm{g} /$ $\mathrm{m}^{3}$ ). Dhahran locations 1 and 2 recorded an overall minimum and maximum $\mathrm{PM}_{10}$ concentration of about 67 and $303 \mu \mathrm{g} / \mathrm{m}^{3}$, respectively [22].

As shown in Figure 3(a), PM in the 3 samples' collection sites in Dhahran showed a trend which suggests that variations occur in the $\mathrm{PM}_{10}$ measurement obtained for all the period of samples (7 days), and the largest level was recorded in location 1 on October 5, 2015. The high $\mathrm{PM}_{10}$ concentration could be attributed to high wind conditions and widespread dust observed on Oct. 5 as shown in Table 2.

In Khobar, Figure 3(b) the average concentration of PM $380 \mu \mathrm{g} / \mathrm{m}^{3}$ was recorded and this is more than the standard level set by USEPA, WHO, and PME which is $150 \mu \mathrm{g} / \mathrm{m}^{3}$, $50 \mu \mathrm{g} / \mathrm{m}^{3}$, and $350 \mu \mathrm{g} / \mathrm{m}^{3}$, respectively. The minimum $\mathrm{PM}_{10}$ concentration of $94 \mu \mathrm{g} / \mathrm{m}^{3}$ was recorded in Khobar (location 2) on Oct. 23, 2015, while a maximum $\mathrm{PM}_{10}$ concentration of $1575 \mu \mathrm{g} / \mathrm{m}^{3}$ was recorded in location 1 on Oct. 22, 2015. Table 2 shows that Haze-widespread dust-mist-cloudy weather conditions were recorded on Oct. 22, 2015. This high widespread weather conditions could be responsible for the high $\mathrm{PM}_{10}$ concentration observed on Oct. 22. The dissimilar trend observed in Khobar location 3 (Figure 3(b)) also indicates that temporal variation affects the concentration level of $\mathrm{PM}_{10}$. Hence, particulate matter concentration could be affected by temporal and spatial variation.

As observed from Figure 3(c), Dammam $\mathrm{PM}_{10}$ sample has an average concentration $127 \mu \mathrm{g} / \mathrm{m}^{3}$, and this is lower than the standard set by both USEPA $\left(150 \mu \mathrm{g} / \mathrm{m}^{3}\right)$ and PME $\left(350 \mu \mathrm{g} / \mathrm{m}^{3}\right)$ but above the standard set by WHO $\left(50 \mu \mathrm{g} / \mathrm{m}^{3}\right)$. In Dammam, the maximum concentration of $\mathrm{PM}_{10}$ was recorded on Nov. 18, 2015, at location $1\left(233 \mu \mathrm{g} / \mathrm{m}^{3}\right)$, whereas on November 23 at location 2, the lowest $\mathrm{PM}_{10}$ concentration of $57 \mu \mathrm{g} / \mathrm{m}^{3}$ was recorded. It is important to note that the comparatively smaller temperature and serene weather condition witnessed in Dammam during the sampling period (Table 2) may be the reason why the PM concentration measured in the city is lower when compared to other cities investigated for this study.

As it is mainly a residential area, Dhahran records lower $\mathrm{PM}_{10}$ concentration than Khobar, which is a high traffic and business district. It was expected that the city of Dammam would have higher $\mathrm{PM}_{10}$ concentration than Dhahran as it is a highly populated district hosting the main port and airport of the Eastern Province; however, results showed that the $\mathrm{PM}_{10}$ concentration in Dammam was lower than in Dhahran and Khobar. This could be attributed to clear weather conditions reported in Dammam during sample collection. In order to identify local weather impacts on $\mathrm{PM}_{10}$ concentration, simultaneous sample collection should be performed over the three cities considered in the study, but as this study is limited to use only one air sample collector, we could not perform simultaneous measurements. Based on the collected air samples, it is concluded that the mean daily $\mathrm{PM}_{10}$ concentration around the city of Khobar was the highest among the three cities.

3.2. Morphology Characteristics of PM Samples. Airborne particulate matter (PM) could be in the form of gaseous contaminants $(0.0005-0.005 \mu \mathrm{m})$, particulate contaminants (0.01-100 $\mu \mathrm{m})$, biological contaminants $(0.5-10 \mu \mathrm{m})$, or dust 


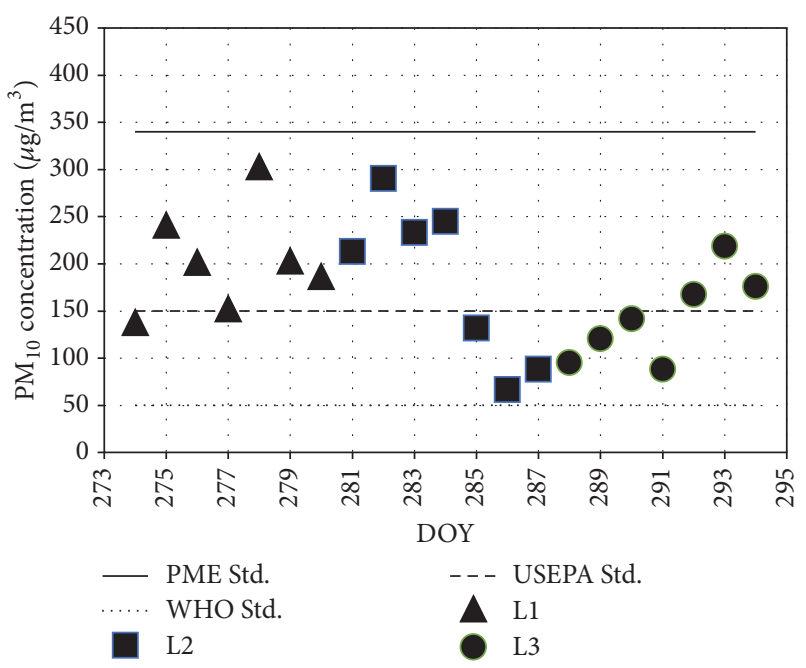

(a) Dhahran Oct. 2015

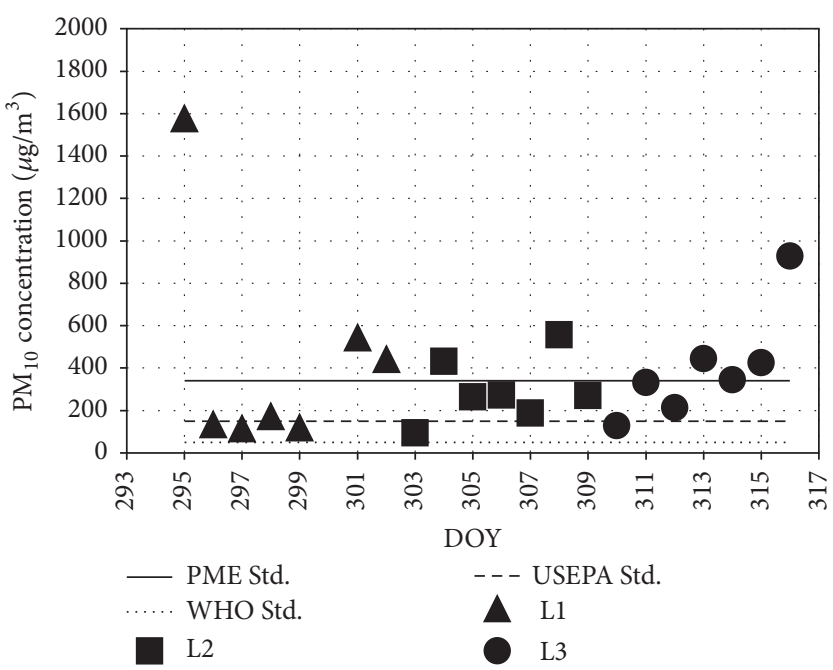

(b) Khobar Oct. \& Nov. 2015

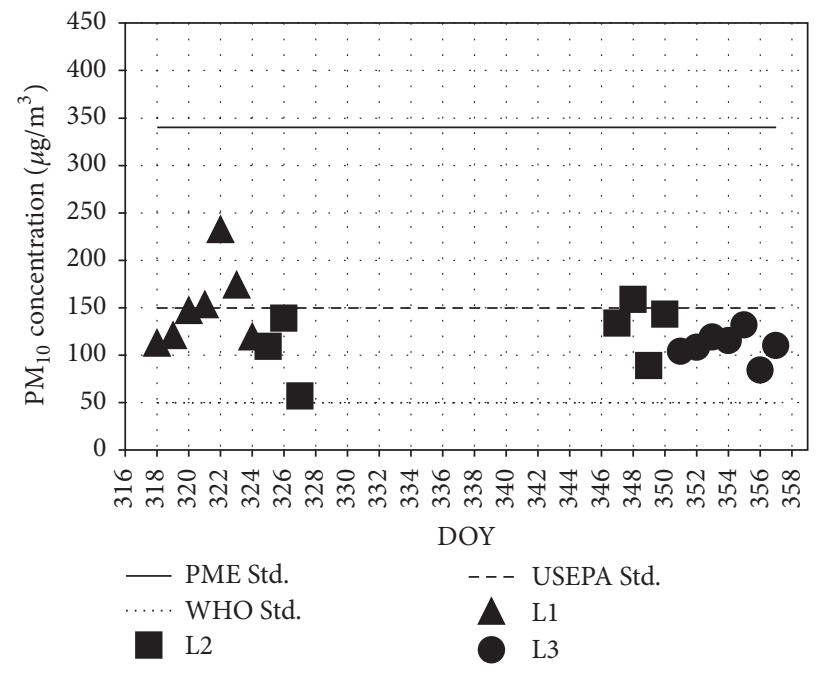

(c) Dammam Nov. \& Dec. 2015

Figure 3: (a) $\mathrm{PM}_{10}$ concentration in Dhahran L1: Location 1, L2: Location 2, and L3: Location 3, DOY: day of the year, (b) $\mathrm{PM}_{10}$ concentration in Khobar L1: Location 1, L2: Location 2, and L3: Location 3, and (c) PM $_{10}$ concentration in Dammam L1: Location 1, L2: Location 2, and L3: Location 3.

(0005-1000 $\mu \mathrm{m})$. The shape of the PM may vary according to the source, type, or mode of formation from spherical (pollen) to irregular (dust) to platy (clay particles). The FESEM micrographs present in Figures 4(a)-4(d) show the morphology of the particulate matter collected from Dhahran, Khobar, and Dammam cities, respectively, along with an image of a blank filter prior samples collection. $\mathrm{PM}_{10}$ samples from Dhahran have size range between 2 and $6 \mu \mathrm{m}$ and formed agglomerates, $\mathrm{PM}_{10}$ samples collected in Khobar were between 1 and $4 \mu \mathrm{m}$ and dense, while those from Dammam shows that the samples are dispersed and their size is between 1 and $6 \mu \mathrm{m}$. The images show that the size of particles from all the sampling cities is below $10 \mu \mathrm{m}$. Based on locations, there are different particle shapes. The shape of particles collected from Dhahran is mostly rodlike and platy in shape and from Khobar is mostly irregular in shape while particles collected from Dammam are nearly spherical. Images of the particles from the 3 cities suggest that the particles are predominantly from geogenic sources such as sea spray or windblown dust. The difference in particles' shape and size indicates that their physical properties are spatially dependent.

3.3. Elemental Composition of PM Samples. In order to assess the variations in the levels of elements collected in the 3 cities as considered in this study, EDX and XRF analysis are used and the result is shown in Figures 5(a)-5(c). It is important to state that XRF analysis cannot detect elements lower than $\mathrm{Na}$ in the periodic table. It is also important to understand that both the EDX and XRF analysis represent the ratio of the elements in the filter sample tested and not the actual concentration. In order to make a comparison between EDX and XRF data, we determined the ratio between each element and the $\mathrm{Si}$ as a reference element as it was detected with a 


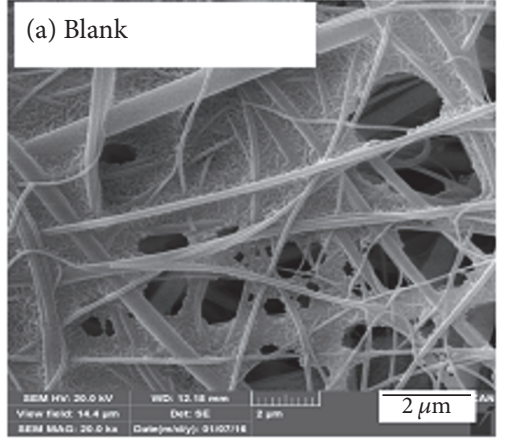

(a)

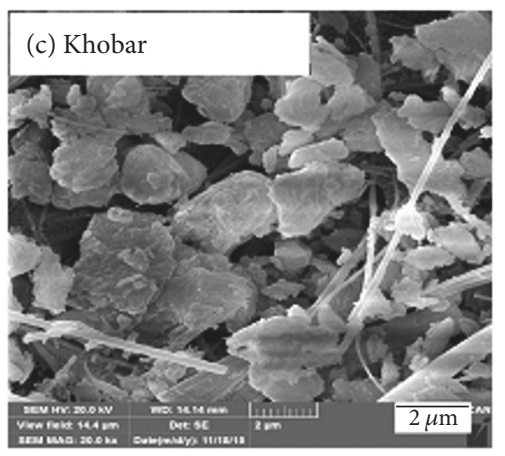

(c)

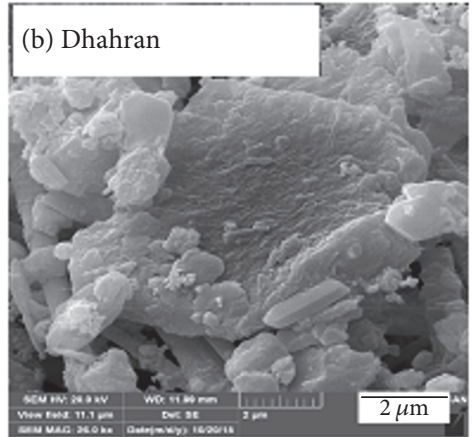

(b)

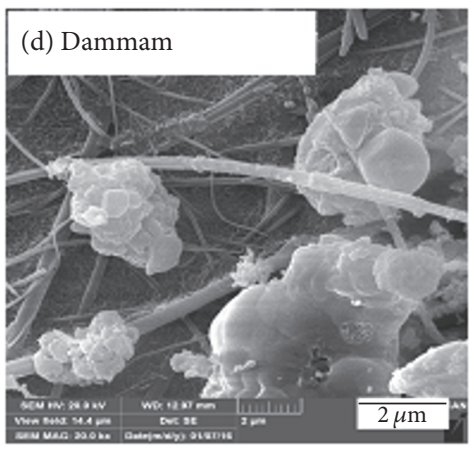

(d)

FIGURE 4: FESEM image analysis showing the morphology of $\mathrm{PM}_{10}$ samples (a) blank filter, (b) Dhahran, (c) Khobar, and (d) Dammam.

significant percentage in both EDX and XRF analysis. Results revealed the presence of $\mathrm{C}, \mathrm{O}, \mathrm{F}, \mathrm{Na}, \mathrm{Mg}, \mathrm{Al}, \mathrm{Si}, \mathrm{K}, \mathrm{Ca}, \mathrm{Fe}, \mathrm{Zn}$, $\mathrm{Ba}, \mathrm{Cl}, \mathrm{S}$, and $\mathrm{Ti}$ in Dhahran. $\mathrm{Zn}$ and Ti were not recorded in Khobar, while samples from Dammam contained C, O, F, Na, $\mathrm{Mg}, \mathrm{Al}, \mathrm{Si}, \mathrm{K}, \mathrm{Ca}$, and $\mathrm{Zn}$. The element that has the largest weight percentage among the three cities sampled was $\mathrm{O}$, followed by $\mathrm{C}$ in Khobar and Dammam and by $\mathrm{F}$ in Dhahran.

The prominent use of air conditions throughout the sampling period could be the reason for this observation. $\mathrm{C}$, $\mathrm{Ca}, \mathrm{O}$, and $\mathrm{Si}$ have huge percentage composition in all the cities sampled, indicating that silica and calcite are present in the samples. Clay mineral may be present in the collected samples in the different cities because of the presence of $\mathrm{Al}$, $\mathrm{Si}, \mathrm{Ca}, \mathrm{Na}, \mathrm{Mg}$, and Fe. Dammam has the highest percentage composition of $\mathrm{Si}$ and $\mathrm{Ca}$, while the highest composition of $\mathrm{C}, \mathrm{O}$, and $\mathrm{S}$ is found in Khobar. Dhahran samples contained high percentage composition of $\mathrm{Ti}, \mathrm{Al}, \mathrm{Ba}, \mathrm{F}, \mathrm{Na}$, and $\mathrm{Mg}$. $\mathrm{CaSO}_{4}$ may be present in the sample due to the presence of $\mathrm{Ca}, \mathrm{C}, \mathrm{O}$, and $\mathrm{S}$. This may be attributed to the interaction between atmospheric sulfur and soil materials from the crust. Natural sources may be the probable origin of the particles as indicated by the occurrence of metals in the samples.

There is a high likelihood of the presence of calcite and silica in the samples due to large percentages of $\mathrm{C}, \mathrm{Ca}, \mathrm{O}$, and Si found in the three cities samples.

The results of this finding show that spatial or temporal disparities do not affect the type of elements observed in sample while affecting their percent composition. This is consistent with outcome of earlier studies [13, 23, 24].
TABLE 3: Trace metal levels in PM samples collected from Dhahran, Khobar, and Dammam.

\begin{tabular}{lccc}
\hline Element & $\begin{array}{c}\text { Dhahran } \\
(\mu \mathrm{g} / \mathrm{L})\end{array}$ & $\begin{array}{c}\text { Khobar } \\
(\mu \mathrm{g} / \mathrm{L})\end{array}$ & $\begin{array}{c}\text { Dammam } \\
(\mu \mathrm{g} / \mathrm{L})\end{array}$ \\
\hline $\mathrm{As}$ & $<1 \times 10^{-2}$ & $<1 \times 10^{-2}$ & $<1 \times 10^{-2}$ \\
$\mathrm{Ba}$ & 5.11 & 8.91 & 10.13 \\
$\mathrm{Cd}$ & $<5 \times 10^{-3}$ & $<5 \times 10^{-3}$ & $<5 \times 10^{-3}$ \\
$\mathrm{Co}$ & $<1 \times 10^{-3}$ & $<1 \times 10^{-3}$ & $<2 \times 10^{-3}$ \\
$\mathrm{Cr}$ & $<6 \times 10^{-2}$ & $<7 \times 10^{-2}$ & $<6 \times 10^{-2}$ \\
$\mathrm{Cu}$ & $2 \times 10^{-2}$ & $3 \times 10^{-2}$ & $1 \times 10^{-2}$ \\
$\mathrm{Mn}$ & $6 \times 10^{-2}$ & $11 \times 10^{-2}$ & $1 \times 10^{-2}$ \\
$\mathrm{Mo}$ & $<3 \times 10^{-3}$ & $<3 \times 10^{-3}$ & $<5 \times 10^{-3}$ \\
$\mathrm{Ni}$ & $2 \times 10^{-2}$ & $2 \times 10^{-2}$ & $1 \times 10^{-2}$ \\
$\mathrm{~V}$ & $5 \times 10^{-2}$ & $7 \times 10^{-2}$ & $6 \times 10^{-2}$ \\
$\mathrm{Zn}$ & 8.98 & 12.64 & 8.87 \\
$\mathrm{Ti}$ & 0.66 & 0.99 & 1.47 \\
$\mathrm{Se}$ & $<1 \times 10^{-2}$ & $<1 \times 10^{-2}$ & $<4 \times 10^{-3}$ \\
$\mathrm{~Pb}$ & $\mathrm{NA}$ & $\mathrm{NA}$ & $<1 \times 10^{-3}$ \\
\hline
\end{tabular}

3.4. Trace Metals Associated with PM Samples. Fourteen (14) trace metals of interest were measured by ICP results and listed in Table 3. As has a concentration of $<0.01 \mu \mathrm{g} / \mathrm{L}$ in the 3 cities, which is below the allowable limit of As concentration in ambient air [25]. The concentration of $\mathrm{Ba}$ in all the cities considered for this study is high, and the highest level 


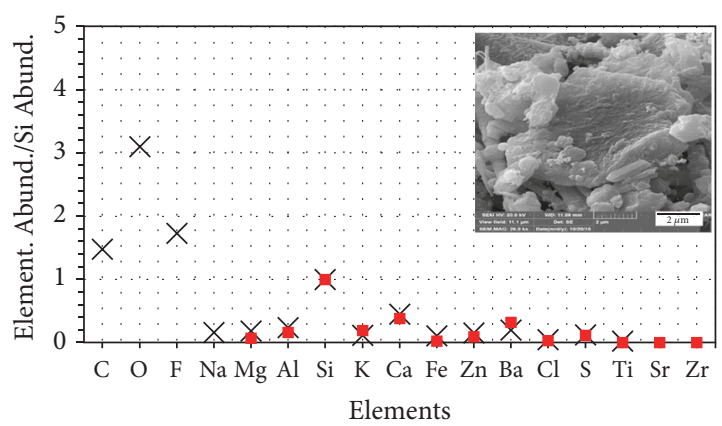

$\times$ EDX

- XRF

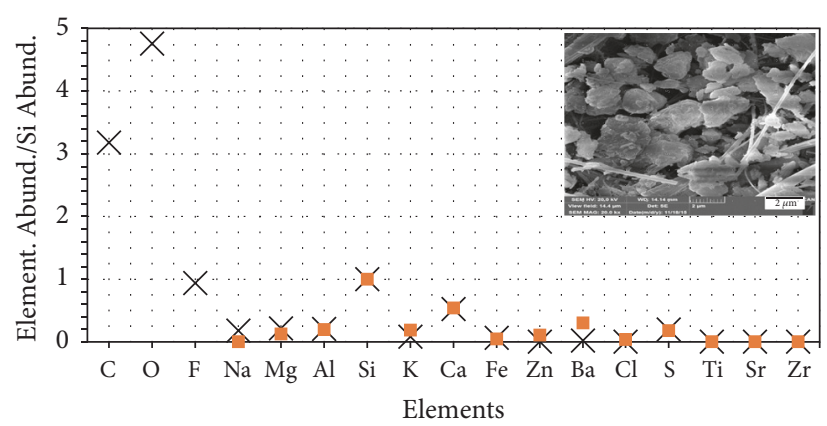

$\times$ EDX

$\square \mathrm{XRF}$

(b)

(a)

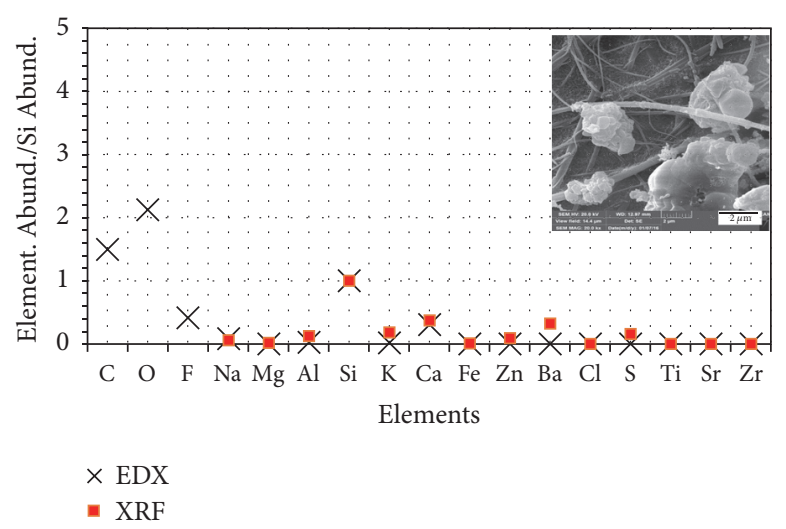

(c)

FIGURE 5: Distribution of elemental structure of particulate matter collected from (a) Dhahran, (b) Khobar, and (c) Dammam using XRF techniques.

was recorded in Dammam $(10.13 \mu \mathrm{g} / \mathrm{L})$ while $5.11 \mu \mathrm{g} / \mathrm{L}$ and $8.91 \mu \mathrm{g} / \mathrm{L}$ were recorded in Dhahran and Khobar, respectively. The most dangerous pollutant for organisms, Cadmium, has a concentration lower than $0.005 \mu \mathrm{g} / \mathrm{m}^{3}$ in all samples collected, which is lower than United States' typical industrial and urban area [26]. In all sampling sites, Co was present at varying concentrations. Dhahran and Khobar samples have Cd concentration that is below $0.001 \mu \mathrm{g} / \mathrm{L}$, while Dammam samples have Cd concentration below $0.002 \mu \mathrm{g} / \mathrm{L}$. According to FDA 2013, the maximum allowable limit of Co is $0.005 \mathrm{mg} / \mathrm{L}$; hence, this is not considered a significant threat. In Dhahran, Khobar, and Dammam, the concentration of Chromium (Cr) was found to be $0.06,0.07$, and $0.06 \mu \mathrm{g} / \mathrm{m}^{3}$, respectively. $\mathrm{Cr}$ concentration is above the threshold recorded in metropolitan and industrialized areas in a typical ambient air in the United States [27]. The concentration of copper was found to be $0.02,0.03$, and $0.01 \mu \mathrm{g} / \mathrm{L}$ Dhahran, Khobar, and Dammam, respectively. Manganese $(\mathrm{Mn})$ has a concentration of $0.01 \mu \mathrm{g} / \mathrm{L}, 0.06 \mu \mathrm{g} / \mathrm{L}$, and $0.11 \mu \mathrm{g} / \mathrm{L}$ in Dammam, Dhahran, and Khobar, respectively. The concentration of $\mathrm{Mn}$ in PM samples from Dhahran and Khobar is relatively higher than what had been reported in previous studies [28]. In Dhahran and Khobar, the concentration of Molybdenum (Mo) is less than $0.03 \mu \mathrm{g} / \mathrm{L}$ while it is below $0.005 \mu \mathrm{g} / \mathrm{L}$ in Dammam. The concentration of Nickel in Dhahran and Khobar is $0.02 \mu \mathrm{g} / \mathrm{L}$ whereas it is $0.01 \mu \mathrm{g} / \mathrm{L}$ in Dammam. Based on EU and USEPA standards, the concentration of Ni in Dhahran and Khobar is the highest level allowed outdoors (ambient air). Vanadium concentration in Dhahran, Khobar, and Dammam was found to be $0.05 \mu \mathrm{g} / \mathrm{L}, 0.07 \mu \mathrm{g} / \mathrm{L}$, and $0.06 \mu \mathrm{g} / \mathrm{L}$, respectively. Zinc concentration was very high in all three cities, with the maximum level measured in Khobar $(12.64 \mu \mathrm{g} / \mathrm{L})$ while the concentration of $8.98 \mu \mathrm{g} / \mathrm{L}$ and $8.87 \mu \mathrm{g} / \mathrm{L}$ was recorded in Dhahran and Dammam, respectively. Dhahran, Khobar, and Dammam have titanium concentration of $0.66 \mu \mathrm{g} / \mathrm{L}$, $0.99 \mu \mathrm{g} / \mathrm{L}$, and $1.47 \mu \mathrm{g} / \mathrm{L}$, respectively. The lead was found at a very low concentration $(<0.001 \mu \mathrm{g} / \mathrm{L})$ in Dammam but not detected in Dhahran and Khobar air samples.

\section{Conclusion}

Characteristics of particulate matter with an Equivalent Aerodynamic Diameters (EAD) below $10 \mu \mathrm{m}$ in tricities of Dhahran (residential district), Khobar (traffic hub), and Dammam (residential district, seaport/airport hub), Saudi Arabia, were determined. It was found that the average daily concentrations in Dhahran, Khobar, and Dammam are $\sim 177 \mu \mathrm{g} / \mathrm{m}^{3}, 379 \mu \mathrm{g} / \mathrm{m}^{3}$, and $126 \mu \mathrm{g} / \mathrm{m}^{3}$, respectively. Particles shapes were found to vary from irregular, platy, spherical, rod-like, and angular. Different elements like Al, 
$\mathrm{Ba}, \mathrm{C}, \mathrm{Ca}, \mathrm{F}, \mathrm{Fe}, \mathrm{K}, \mathrm{Na}, \mathrm{O}$, and $\mathrm{Si}$ were detected varying percentage by weight of the samples. $\mathrm{Cr}, \mathrm{Zn}, \mathrm{Ni}, \mathrm{Ti}$, and $\mathrm{V}$ measurements show concentration above the maximum allowable limit; however, other trace metals were found below the maximum allowable limits. It was found that the spatial distribution of the PM measurements affects the form, shape, and size of airborne PM but not the elements they contain.

\section{Conflicts of Interest}

The authors declare that they have no conflicts of interest.

\section{Acknowledgments}

This research work was funded by the Deanship of Scientific Research (DSR) of King Fahd University of Petroleum and Minerals (KFUPM), with Project no. IN141051. The authors also acknowledge Center for Environment and Water (CEW) and Center of Excellence in Nanotechnology (CENT) of KFUPM Research Institute for providing analytical instruments used in the research work.

\section{References}

[1] J. Cao, "Evolution of PM2.5 Measurements and Standards in the U.S. and Future Perspectives for China," Aerosol and Air Quality Research, pp. 1197-1121, 2013.

[2] A. Farahat, H. El-Askary, and A. U. Dogan, "Aerosols size distribution characteristics and role of precipitation during dust storm formation over Saudi Arabia," Aerosol and Air Quality Research, vol. 16, no. 10, pp. 2523-2534, 2016.

[3] A. Farahat, H. El-Askary, P. Adetokunbo, and A.-T. Fuad, "Analysis of aerosol absorption properties and transport over North Africa and the Middle East using AERONET data," Annales Geophysicae, vol. 34, no. 11, pp. 1031-1044, 2016.

[4] M. Kampa and E. Castanas, "Human health effects of air pollution," Environmental Pollution (Barking, Essex: 1987), vol. 151, no. 2, pp. 362-367, 2008.

[5] E. G. Stephanou, Aerosols PM10 and PM2.5, vol. 1, University of Crete, Heraklion, Greece, 2012.

[6] Z. Wu, F. Liu, and W. Fan, "Characteristics of PM10 and PM2.5 at Mount Wutai Buddhism Scenic Spot, Shanxi, China," The Atmosphere, vol. 6, no. 8, pp. 1195-1210, 2015.

[7] M. T. Ny and B. K. Lee, "Size distribution of airborne particulate matter and associated metallic elements in an urban area of an industrial city in Korea," Aerosol and Air Quality Research, vol. 6, pp. 643-653, 2011.

[8] H. Ahmady-Birgani, H. Mirnejad, S. Feiznia, and K. G. McQueen, "Mineralogy and geochemistry of atmospheric particulates in western Iran," Atmospheric Environment, vol. 119, pp. 262-272, 2015.

[9] D. J. Moschandreas, "Characterization of indoor air pollution," Journal of Wind Engineering \& Industrial Aerodynamics, vol. 21, no. 1, pp. 39-49, 1985.

[10] H. Fromme, J. Diemer, S. Dietrich et al., "Chemical and morphological properties of particulate matter (PM10, PM2.5) in school classrooms and outdoor air," Atmospheric Environment, vol. 42, no. 27, pp. 6597-6605, 2008.

[11] J. Boman, A. Wagner, and M. J. Gatari, "Trace elements in PM2.5 in Gothenburg, Sweden," Spectrochimica Acta Part B: Atomic Spectroscopy, vol. 6, pp. 478-482, 2010.
[12] A. S. Pipal, A. Kulshrestha, and A. Taneja, "Characterization and morphological analysis of airborne PM2.5 and PM10 in Agra located in north central India," Atmospheric Environment, vol. 45, no. 21, pp. 3621-3630, 2011.

[13] P. G. Satsangi and S. Yadav, "Characterization of PM2.5 by X-ray diffraction and scanning electron microscopy-energy dispersive spectrometer: Its relation with different pollution sources," International Journal of Environmental Science and Technology, vol. 11, no. 1, pp. 217-232, 2013.

[14] A. K. Singh, M. K. Srivastava, M. Singh, A. Srivastava, and S. Kumar, "Characterization of Atmospheric Aerosol by SEMEDX and Ion- Chromatography Techniques for Eastern IndoGangetic Plain Location, Varanasi, India," International Journal of Advances in Earth Sciences, vol. 3, no. 2, pp. 41-51, 2014.

[15] A. Farahat, "Air pollution in the Arabian Peninsula (Saudi Arabia, the United Arab Emirates, Kuwait, Qatar, Bahrain, and Oman): causes, effects, and aerosol categorization," Arabian Journal of Geosciences, vol. 9, no. 3, article 196, 2016.

[16] B. Alharbi, M. M. Shareef, and T. Husain, "Study of chemical characteristics of particulate matter concentrations in Riyadh, Saudi Arabia," Atmospheric Pollution Research, vol. 6, no. 1, pp. 88-98, 2015.

[17] T. Hussein, M. A. Alghamdi, M. Khoder et al., "Particulate matter and number concentrations of particles larger than 0.25 $\mu \mathrm{m}$ in the urban atmosphere of Jeddah, Saudi Arabia," Aerosol and Air Quality Research, vol. 14, no. 5, pp. 1383-1391, 2014.

[18] A. S. Modaihsh and M. O. Mahjou, "Falling Dust Characteristics in Riyadh City, Saudi Arabia During Winter Months," APCBEE Procedia, vol. 5, pp. 50-58, 2013.

[19] M. Sadiq and A. A. Mian, "Nickel and vanadium in air particulates at Dhahran (Saudi Arabia) during and after the Kuwait oil fires," Atmospheric Environment, vol. 28, no. 13, pp. 2249-2253, 1994.

[20] WHO, "Air Quality Guidelines - Particulate matter, ozone, nitrogen dioxide and sulfur dioxide," WHO Europe Publication, vol. 4, pp. 67-105, 2005.

[21] USEPA, "National Ambient Air Quality Standards. Air and Radiation," US EPA, (2), 3-4, http://epa.gov/air/criteria.htm, 2014.

[22] Presidency of Meteorology and Standards (PME), "Environmental Standards Ambient Air Quality," Saudi Arabia, 2014.

[23] A. S. Modaihsh, "Characteristics and composition of the falling dust sediments on Riyadh city, Saudi Arabia," Journal of Arid Environments, vol. 36, no. 2, pp. 211-223, 1997.

[24] W. Chung, V. N. Sharifi, and J. Swithenbank, "Characterization of Airborne Particulate Matter in a City Environment," 17-32, 2008.

[25] A. Shaltout, J. Boman, B. Welz et al., "Method development for the determination of $\mathrm{Cd}, \mathrm{Cu}, \mathrm{Ni}$ and $\mathrm{Pb}$ in PM2.5 particles sampled in industrial and urban areas of Greater Cairo, Egypt, using high-resolution continuum source graphite furnace atomic absorption spectrometry," Microchemical Journal, vol. 113, no. 4-9, 2014.

[26] M. B. McBride, H. A. Shayler, H. M. Spliethoff et al., "Concentrations of lead, cadmium and barium in urban gardengrown vegetables: The impact of soil variables," Environmental Pollution, vol. 194, pp. 254-261, 2014.

[27] FDA, "Cadmium Toxicity: What are the U.S. Standards for Cadmium Exposure," Environmental Health, and Medicine Education. Agency for Toxic Substances \& Disease Registry, https://www.atsdr.cdc.gov, 2013. 
[28] A. A. Shaltout, J. Boman, Z. F. Shehadeh, D.-A. R. Al-Malawi, O. M. Hemeda, and M. M. Morsy, "Spectroscopic investigation of PM2.5 collected at industrial, residential and traffic sites in Taif, Saudi Arabia," Journal of Aerosol Science, vol. 79, pp. 97108, 2015. 

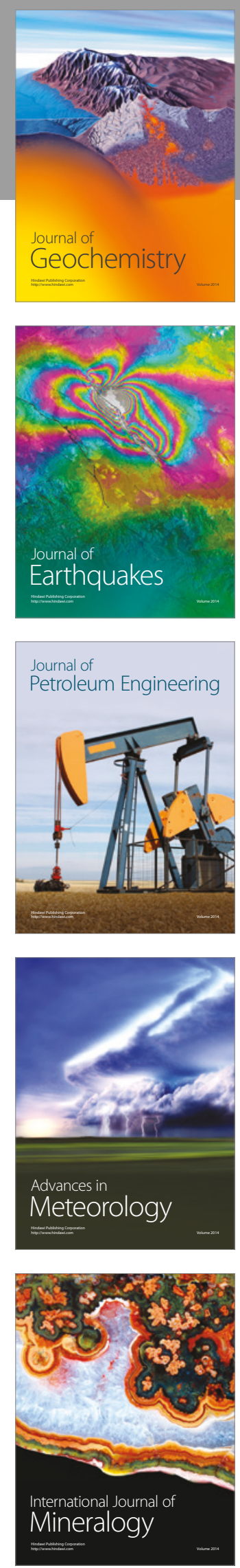
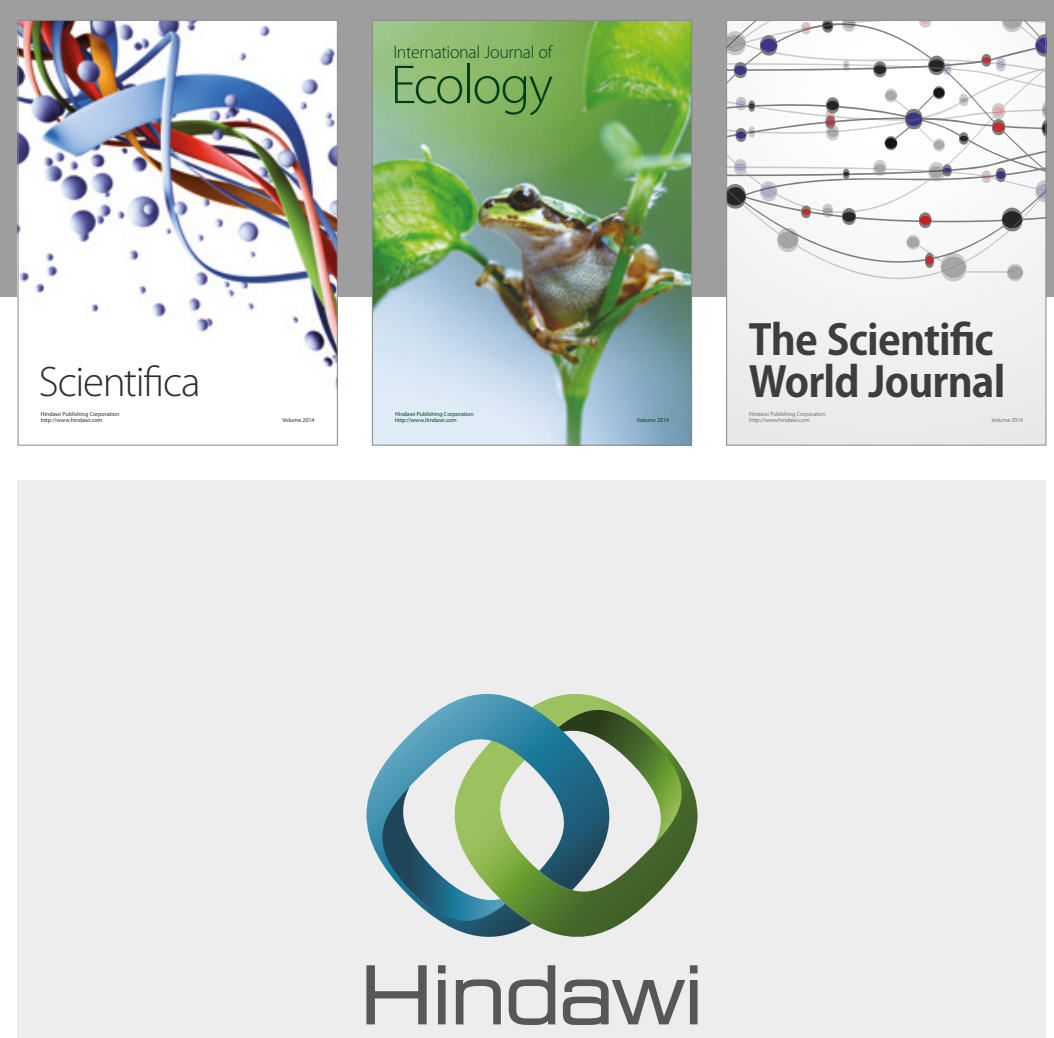

Submit your manuscripts at

https://www.hindawi.com
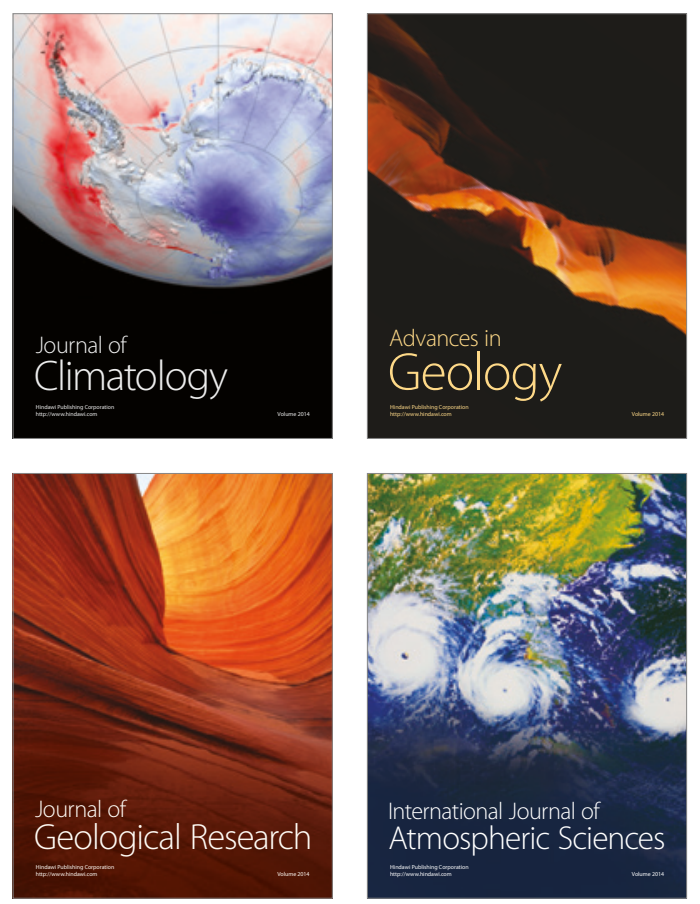

The Scientific

World Journal
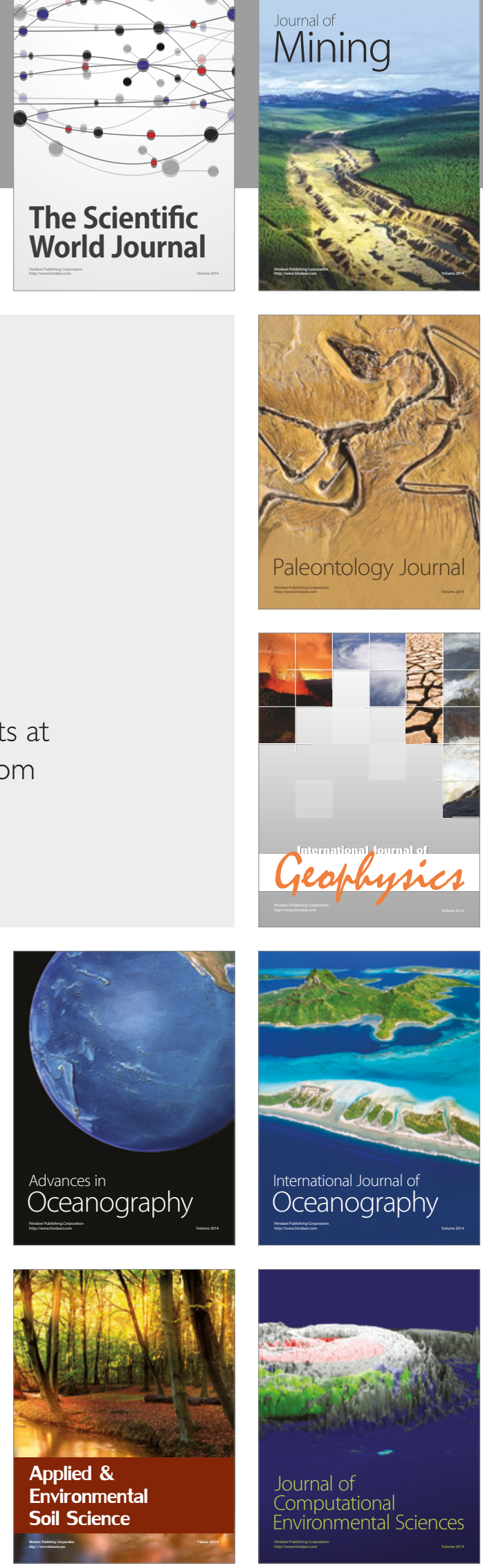